\title{
Genetic variation in serum protein pattern and blood $\beta$-hydroxybutyrate and their relationships with udder health traits, protein profile, and cheese-making properties in Holstein cows
}

\author{
Alessio Cecchinato,, ${ }^{* 1}$ Tania Bobbo, ${ }^{*}$ Pamela L. Ruegg, $†$ Luigi Gallo, ${ }^{*}$ Giovanni Bittante, ${ }^{*}$ and Sara Pegolo* \\ *Department of Agronomy, Food, Natural Resources, Animals and Environment (DAFNAE), University of Padova, 35020 Legnaro, Padova, Italy \\ †Department of Animal Science, Michigan State University, East Lansing 48824
}

\begin{abstract}
The aim of this study was to investigate in Holstein cows the genetic basis of blood serum metabolites [i.e., total protein, albumin, globulin, albumin:globulin ratio $(\mathrm{A}: \mathrm{G})$, and blood $\beta$-hydroxybutyrate (BHB)], a set of milk phenotypes related to udder health, milk quality technological characteristics, and genetic relationships among them. Samples of milk were collected from 498 Holstein cows belonging to 28 herds. All animal welfare and milk phenotypes were assessed using standard analytical methodology. A set of Bayesian univariate and bivariate animal models was implemented via Gibbs sampling, and statistical inference was based on the marginal posterior distributions of parameters of concern. We observed a small additive genetic influence for serum albumin concentrations, moderate heritability $(\geq 0.20)$ for total proteins, globulins, and A:G, and high heritability (0.37) for blood BHB. Udder health traits (somatic cell score, milk lactose, and milk $\mathrm{pH}$ ) showed low or moderate heritabilities (0.15-0.20), whereas variations in milk protein fraction concentrations were confirmed as mostly under genetic control (heritability: 0.21-0.71). The moderate and high heritabilities observed for milk coagulation properties and curd firming modeling parameters provided confirmation that genetic background exerts a strong influence on the cheese-making ability of milk, largely due to genetic polymorphisms in the major milk protein genes. Blood BHB showed strong negative genetic correlations with globulins $(-0.619)$ but positive correlations with serum albumin (0.629) and A:G (0.717), which suggests that alterations in the serum protein pattern and BHB blood levels are likely to be genetically related. Strong relationships were found between albumin and fat percentages $(-0.894)$, between globulin and $\alpha_{\mathrm{S}_{2}} \mathrm{CN}(-0.610)$,
\end{abstract}

Received April 18, 2018.

Accepted August 24, 2018.

${ }^{1}$ Corresponding author: alessio.cecchinato@unipd.it and, to a lesser extent, between serum protein pattern and milk technological characteristics. Genetic relationships between blood BHB and traits related to udder health and milk quality and technological characteristics were mostly weak. This study provides evidence that there is exploitable additive genetic variation for traits related to animal health and welfare and throws light on the shared genetic basis of these traits and the phenotypes related to the quality and cheese-making ability of milk.

Key words: serum albumin, serum globulin, blood $\beta$-hydroxybutyrate, protein fraction, cheese-making

\section{INTRODUCTION}

Blood serum protein pattern (SPP) has been suggested as an indicator of the health status of dairy cows (Giuliotti et al., 2004; Bobbo et al., 2017a). Changes in serum proteins can be indicative of nonspecific pathological processes or may serve as diagnostic markers of some pathological conditions. Within the SPP, total proteins, component albumins and globulins, and the albumin:globulin ratio $(\mathbf{A}: \mathbf{G})$ have several functions. Albumin is synthesized in the liver and is involved in the transport of bilirubin, hormones, metals, vitamins, and drugs. It is also involved in fat metabolism by binding fatty acids and transporting them in the plasma (Busher, 1990). Globulins are a heterogeneous group of blood proteins, including carrier proteins, enzymes, complement, and immunoglobulins, most of which are synthesized in the liver, although the immunoglobulins are synthesized by plasma cells. They can be separated into 4 fractions by electrophoresis: $\alpha_{1^{-}}, \alpha_{2^{-}}$, $\beta-$, and $\gamma$-globulins (Busher, 1990). Physiological and pathological conditions can trigger changes in albumin and globulin concentrations (Alberghina et al., 2010; Overton et al., 2017), which can also be indicators of mammary gland inflammation (Bobbo et al., 2017a,b). In clinical practice, A:G may be useful in identifying endometritis and dysproteinemias (Kaneko et al., 2008; Overton et al., 2017). 
Blood serum proteins may also be useful in assessing the metabolic status of animals at herd level (Cozzi et al., 2011). Stress conditions, such as negative energy balance (NEB) during early lactation, can alter metabolic state and challenge the immune system, causing an increase in production of globulins and albumins (West, 1999). Alterations to a cow's energy balance have also been associated with an increased risk of developing clinical mastitis (O'Rourke, 2009). Blood ketone bodies are direct indicators of energy balance because concentrations are higher in the case of poor carbohydrate status when associated with NEB. $\beta$-Hydroxybutyrate is the ketone body of choice for diagnosing ketosis in dairy cows because it is stable in serum and plasma as well as in milk. Recent studies have predicted blood BHB from milk Fourier transform mid-infrared spectra (Belay et al., 2017a), and although this may be a promising tool for herd-level monitoring of hyperketonemia, it is not accurate enough to detect ketosis in individual cows (van der Drift et al., 2012a; Grelet et al., 2016).

In addition to using SPP and BHB to diagnose clinical mastitis and ketosis, respectively, they might be used as general indicators of the animal's health status by identifying potential metabolic alterations or subclinical disorders. For instance, A:G has recently been reported as a marker of subclinical mastitis or mammary gland inflammation in cows (Gain et al., 2015; Bobbo et al., 2017b) and can generally be considered to be an indicator of immune status (Piccinini et al., 2004). In addition, increased concentrations of BHB are associated with alterations in energy metabolism, which may increase the risk of poor health and reproductive outcomes (Wankhade et al., 2017).

Milk yield and composition may be significantly altered by a variety of factors, including animal health and welfare, and can therefore be considered as indicators of the animal's metabolic and immune status (Mulligan et al., 2006; Bobbo et al., 2017c). Changes in milk composition and, in particular, the proportions of the milk protein fractions are known to affect milk technological characteristics (Wedholm et al., 2006; Jõudu et al., 2008; Bittante et al., 2012). A reduction in the secretion of $\kappa$ - $\mathrm{CN}$ by mammary epithelial cells with IMI (possibly due to postsecretory degradation of proteins by proteinases) seems to be responsible for a loss of stability in caseins and associated with clot formation in milk (Yang et al., 2009).

Genetic analyses have revealed the existence of exploitable genetic variations in bovine blood composition. Additive genetic relationships between blood serum metabolites and milk production traits (e.g., fat and protein) have also been explored (Peterson et al., 1982; Belay et al., 2017b).
Our hypothesis is that SPP might be considered to be an indicator of mammary gland health status and possibly of metabolic alterations in dairy cattle. Moreover, because of the existence of a strict connection between animal health and milk quality, we hypothesized that variation in SPP might also be related to alterations in milk quality and, in turn, the cheese-making aptitude. To our knowledge, the genetic relationships between SPP and BHB and between these traits and udder health traits, milk protein composition, and technological characteristics have not been investigated before. Therefore, the general aim of this work was to assess whether there is exploitable genetic variation of these indicators for breeding purposes and to shed light on their mutual relationships as well as their relationships with a set of phenotypes related to animal health, cow robustness, and cheese-making characteristics. Our specific objectives were to estimate (1) genetic variation and heritability of SPP and BHB in Holstein cows, (2) genetic relationships between SPP and BHB, and (3) additive genetic relationships between these traits and other phenotypes as indicators of udder health (namely, SCS, lactose, and $\mathrm{pH}$ ), milk composition, milk $\mathrm{N}$ fractions, traditional milk coagulation properties, and new curd firming modeling parameters.

\section{MATERIALS AND METHODS}

\section{Animals and Milk Sampling}

The present study is part of the Cowplus Project, described in Bobbo et al. (2017a), which deals with the study of cattle farming in mountain areas. Briefly, blood and milk samples were collected from 1,508 cows of 3 specialized dairy breeds (Holstein Friesian, Brown Swiss, and Jersey) and 3 dual-purpose breeds of Alpine origin (Simmental, Rendena, and Alpine Grey). The cows were housed in 41 multibreed farms (with at least 2 breeds/farm) in the province of Trentino (northeastern Italy), selected to represent the region's 4 different dairy farming systems, previously identified by Sturaro et al. (2013). Within the multibreed farms, for this study and for genetic purposes, we selected 1 specialized dairy breed (i.e., the Holstein Friesian) that is widely represented. The cows were sampled once ( 1 herd per day) after their health status had been determined on the basis of rectal temperature, heart rate, respiratory profile, appetite, and fecal consistency. Only clinically healthy cows at the time of the visit were included in the study.

A milk sample $(50 \mathrm{~mL})$ was taken from each cow during the evening milking by a trained technician and kept at a temperature of $4^{\circ} \mathrm{C}$ (without preservative) 
until processing (within $24 \mathrm{~h}$ ). Blood samples were taken by a veterinarian via jugular venipuncture (VenosafeTM, Terumo Europe, Leuven, Belgium) with no anticoagulant additive. Information on the cows (e.g., parity, stage of lactation) and the herds (e.g., dairy management) was obtained from the Provincial Federation of Breeders (Trento, Italy). For genetic analysis, 498 Holstein Friesian cows from 28 herds were used. The pedigree file was generated by tracing back up to the last known generation. The resulting pedigree file included 3,378 animals up to the fourth generation. The number of sires was 984 , and the number of dams was 1,991. The number of sires with daughters with phenotypic records was 121 (each sire having between 2 and 40 daughters).

\section{Definition of Phenotypes: Blood Sample Analyses: SPP and BHB}

Serum separation was performed on the farm. The blood samples were allowed to clot in tubes for $30 \mathrm{~min}$ after sampling (Tuck et al., 2009) and were then centrifuged at $1,780 \times g$ at $4^{\circ} \mathrm{C}$ for $10 \mathrm{~min}$. Serum was transported at $4^{\circ} \mathrm{C}$ to the laboratory of the Department of Animal Medicine, Production and Health of the University of Padua (Italy), where it was stored at $-18^{\circ} \mathrm{C}$ until analysis. Serum was assessed for total protein and albumin using a BT1500 automated photometer analyzer (Biotecnica Instruments S.p.A., Rome, Italy). Serum total protein was determined by the Biuret method (Gornall et al., 1949), and albumin was determined by the bromocresol green analytical method (Doumas et al., 1971). Globulin was determined as the difference between total protein and albumin concentrations, and we also calculated the ratio between albumin and globulin concentrations. Blood levels of BHB were determined with a Cobas C-501 analyzer (Roche Diagnostics, Mannheim, Germany) using the Ranbut RX Monza test (Randox, Crumlin, UK).

\section{Milk Composition}

An aliquot of each milk sample was analyzed for fat, protein, casein, lactose (\%), and urea (mg/100 g) using a Milkoscan FT6000 (Foss Electric A/S, Hillerød, Denmark) at the Milk Laboratory of the Department of Agronomy, Food, Natural Resources, Animals and the Environment (DAFNAE), University of Padua (Italy). Details of the instrument calibration and reference methods are reported in Bobbo et al. (2016). Somatic cell count was obtained with a Fossomatic Minor (Foss Electric A/S) and log-transformed to SCS $\left[\mathrm{SCS}=\log _{2}(\mathrm{SCC} / 100,000)+3\right]$ according to Ali and
Shook (1980). After adjusting the sample temperature, milk pH was measured with a Crison Basic 25 electrode (Crison Instruments SA, Barcelona, Spain).

\section{Milk Protein Composition}

Separation of the milk protein fractions was performed at DAFNAE's Milk and Cheese Laboratory by reversed-phase HPLC as described by Maurmayr et al. (2013). Milk samples were prepared following the method suggested by Bobe et al. (1998), and analysis was carried out using an Agilent 1260 Series chromatograph (Agilent Technologies, Santa Clara, CA) equipped with a quaternary pump (Agilent 1260 Series, G1311B), and a diode array detector (Agilent 1260 Series, DAD VL+, G1315C). Protein separation was performed using a C8 reversed-phase analytical column (Aeris Widepore XBC8, Phenomenex, Torrance, CA) with large-pore coreshell packing $(3.6 \mu \mathrm{m}, 300 \AA$, $250 \times 2.1$ i.d. $)$. Sample vials were maintained at a constant low temperature $\left(4^{\circ} \mathrm{C}\right)$ and injected via an autosampler (Agilent 1100 Series, G1313A). Each fraction was expressed as the ratio to the total milk $\mathrm{N}$ content. Remaining milk $\mathrm{N}$ compounds were estimated as the difference from the total milk $\mathrm{N}$ content.

\section{Technological Traits}

Traditional Milk Coagulation Properties. Traditional parameters of milk clotting ability were determined in duplicate using a mechanical lactodynamograph (Formagraph, Foss Electric A/S) at DAFNAE's Milk and Cheese Laboratory. These parameters were time from rennet addition to milk gelation (RCT; min), curd-firming rate defined as the time to a curd firmness (CF) of $20 \mathrm{~mm}\left(\mathbf{k}_{\mathbf{2 0}} ; \mathrm{min}\right)$, and $\mathrm{CF}$ at 30,45 , and 60 min from rennet addition $\left(\mathbf{a}_{30}, \mathbf{a}_{45}\right.$, and $\mathbf{a}_{60}$, respectively; mm). Experimental conditions were as reported by Stocco et al. (2017).

Curd Firming Traits. A total of $240 \mathrm{CF}$ values were recorded for each replicate (60-min test; 1 datum every $15 \mathrm{~s}$ ). The curd firming and syneresis traits of each individual milk sample were estimated using the equation proposed by Bittante et al. (2013) and illustrated by Stocco et al. (2017):

$$
\mathrm{CF}_{\mathrm{t}}=\mathrm{CF}_{\mathrm{P}} \times\left[1-\mathrm{e}^{-\mathrm{k}_{\mathrm{CF}} \times\left(\mathrm{t}-\mathrm{RCT}_{\mathrm{eq}}\right)}\right] \times \mathrm{e}^{-\mathrm{k}_{\mathrm{SR}} \times\left(\mathrm{t}-\mathrm{RCT}_{\mathrm{eq}}\right)},
$$

where $\mathbf{C F}_{\mathbf{t}}(\mathrm{mm})$ is the $\mathrm{CF}$ modeled as a function of time t, $\mathbf{C F}_{\mathbf{P}}(\mathrm{mm})$ is the potential asymptotical $\mathrm{CF}$ at infinite time, $\mathrm{k}_{\mathrm{CF}}\left(\% \times \mathrm{min}^{-1}\right)$ is the curd-firming instant rate constant, $\mathrm{k}_{\mathrm{SR}}\left(\% \times \min ^{-1}\right)$ is the curd 
syneresis instant rate constant, and $\mathrm{RCT}_{\mathrm{eq}}$ (min) is the rennet coagulation time. We also measured 2 other traits related to maximum $\mathrm{CF}$ : maximum $\mathrm{CF}_{\mathrm{t}}(\mathrm{mm})$ and time to maximum $\mathrm{CF}_{\mathrm{t}}$ (min).

\section{Statistical Analysis}

Nongenetic Effects. Nongenetic effects, which were included in the mixed models used to estimate the genetic parameters, were identified through a preliminary nongenetic analysis as reported by Bobbo et al. (2017a), with the exception of the effects of herd productivity and breed as all the subsequent genetic analyses were conducted on Holstein Friesians. For all traits, the model accounted for the effects of herd-date [28 levels with an average value of cows/herd equal to $\sim 18$ (minimum $=8 ;$ maximum $=73$ )], DIM [class 1 , $<60$ d ( $\mathrm{n}=91)$; class 2, 60-120 d $(\mathrm{n}=79)$; class 3, 121-180 d ( $\mathrm{n}=81)$; class 4, 181-240 d ( $\mathrm{n}=79)$; class 5, 241-300 d ( $\mathrm{n}=83)$; class $6,>300 \mathrm{~d}(\mathrm{n}=85)]$, and parity (1 to 4 or more, with 158, 134, 102, and 104 cows in first, second, third, and fourth or greater parity, respectively).

Genetic Analysis. We investigated the genetic determinism of SPP, BHB, milk composition, the protein profile, and coagulation properties (y) using the following hierarchical model:

$$
\mathbf{y}=\mathbf{X b}+\mathbf{Z}_{1} \mathbf{h}+\mathbf{Z}_{2} \mathbf{a}+\mathbf{e},
$$

where $\mathbf{y}$ is the vector of phenotypic records with dimension $n$, and $\mathbf{X}, \mathbf{Z}_{1}$, and $\mathbf{Z}_{2}$ are appropriate incidence matrices for the systematic effects (b), herd-date effects (h), and polygenic additive genetic effects (a), respectively. Included in $\mathbf{b}$ are the systematic effects of DIM and parity.

All models were analyzed using a standard Bayesian approach. The priors for $\mathbf{b}$ and the variance components were assumed to be flat. The a priori distributions of $\mathbf{h}$ and $\mathbf{a}$ were assumed to be multivariate normal, as follows:

$$
\begin{aligned}
& p\left(\mathbf{h} \mid \sigma_{h}^{2}\right) \sim N\left(0, \mathbf{I} \sigma_{h}^{2}\right) \\
& p\left(\mathbf{a} \mid \sigma_{a}^{2}\right) \sim N\left(0, \mathbf{A} \sigma_{a}^{2}\right),
\end{aligned}
$$

where $\mathbf{I}$ is an identity matrix with dimensions equal to the number of elements in $\mathbf{h}, \mathbf{A}$ is the numerator relationship matrix between individuals (Wright, 1922; pedigree file comprised 3,378 animals), and $\sigma_{h}^{2}$ and $\sigma_{a}^{2}$ are the herd-date and additive genetic variances, respectively.
To estimate genetic correlations between the traits, we conducted a set of bivariate analyses that implemented Model 1 in its multivariate version. In this case, the involved traits were assumed to jointly follow a multivariate normal distribution along with the additive genetic, herd, and residual effects. Intraherd heritability $\left(\mathrm{h}^{2}\right)$ was computed as $\mathrm{h}^{2}=\sigma_{a}^{2} /\left(\sigma_{a}^{2}+\sigma_{e}^{2}\right)$.

Marginal posterior distributions of all unknowns were estimated by applying the Gibbs sampling algorithm. The program TM (http://snp.toulouse.inra.fr/ alegarra) was used for all Gibbs sampling procedures. The lengths of the chain and the burn-in period were assessed by visual inspection of trace plots. After some preliminary analysis, chains of 850,000 samples were kept, with a burn-in period of 50,000. Subsequently, 1 in every 100 successive samples was retained.

The posterior mean was used as the point estimate for all parameters. Lower and upper bounds of the highest 95\% probability density regions were obtained from the estimated marginal densities and used to bound heritability estimates. For the phenotypic, genetic, herd, and residual correlations, in addition to the mean of each marginal posterior distribution, we estimated the probability of the corresponding correlation being greater than 0 when the mean is positive or lower than 0 when the mean is negative $(\mathrm{P})$. We considered all estimates with $\mathrm{P}$ greater than $95 \%$ as relevant correlations. A more detailed description of these features can be found in Blasco (2005).

\section{RESULTS AND DISCUSSION}

\section{Descriptive Statistics}

Detailed description of the entire data set, specifically on breed characteristics and the genetic background, has been reported in Bobbo et al. (2017a). Descriptive statistics for blood serum metabolites, udder health traits, and milk composition and technological characteristics for Holstein cows are reported in Table 1. Concentrations of blood serum total proteins averaged $75.23 \mathrm{~g} / \mathrm{L}$, and globulins were the most representative fraction $(44.53 \mathrm{~g} / \mathrm{L})$. The average A:G was 0.70 . The average BHB level was $0.59 \mathrm{mmol} / \mathrm{L}$ but was highly variable $(\mathrm{CV}=38 \%)$. Higher values of $\mathrm{BHB}$ have been reported in the literature across early lactation (DenisRobichaud et al., 2014; Belay et al., 2017a,b). Among the milk $\mathrm{N}$ fractions, major casein fractions were $\beta$-CN and $\alpha_{\mathrm{S} 1}{ }^{-} \mathrm{CN}$ (29.68 and $29.49 \%$ of milk $\mathrm{N}$, respectively), whereas $\beta$-LG was the most common whey protein $(13.58 \%$ of milk $\mathrm{N})$, in agreement with previous findings (Schopen et al., 2011; Bernabucci et al., 2015; Buitenhuis et al., 2016). 
Regarding milk technological properties, samples coagulated about 20 min after rennet addition (RCT), and a curd firmness of $20 \mathrm{~mm}\left(\mathrm{k}_{20}\right)$ was obtained after about $5 \mathrm{~min}$. Curd firmness at $30 \mathrm{~min}$ was around 35 $\mathrm{mm}$. The average values we obtained are somewhat higher than those reported in the literature for the same breed, as reviewed by Bittante et al. (2012), but

Table 1. Descriptive statistics for the investigated traits $(\mathrm{n}=498)$

\begin{tabular}{|c|c|c|}
\hline Item & Mean & $\mathrm{CV}, \%$ \\
\hline \multicolumn{3}{|l|}{ Serum protein pattern, g/L } \\
\hline Total protein & 75.23 & 7 \\
\hline Albumin & 30.70 & 7 \\
\hline Globulin & 44.53 & 13 \\
\hline Albumin:globulin & 0.70 & 15 \\
\hline BHB, mmol/L & 0.59 & 38 \\
\hline \multicolumn{3}{|l|}{ Udder health traits } \\
\hline $\mathrm{SCS}^{1}$ & 3.04 & 64 \\
\hline Lactose, \% & 4.82 & 5 \\
\hline $\mathrm{pH}$ & 6.51 & 1 \\
\hline Milk yield, kg/d & 28.4 & 35 \\
\hline True protein $\mathrm{N}, \%$ of total milk $\mathrm{N}$ & 92.06 & 4 \\
\hline \multicolumn{3}{|l|}{ Milk $\mathrm{N}$ fractions, ${ }^{2} \%$ of total milk $\mathrm{N}$} \\
\hline Caseins & 76.79 & 4 \\
\hline$\beta-\mathrm{CN}$ & 29.68 & 8 \\
\hline$\kappa-\mathrm{CN}$ & 8.16 & 18 \\
\hline$\alpha_{\mathrm{S}_{1}-\mathrm{CN}}$ & 29.49 & 8 \\
\hline$\alpha_{\mathrm{S}^{-}} \mathrm{CN}$ & 7.13 & 21 \\
\hline Casein fragments & 2.33 & 40 \\
\hline Whey proteins & 15.91 & 20 \\
\hline$\beta-\mathrm{LG}$ & 13.58 & 21 \\
\hline$\alpha-\mathrm{LA}$ & 2.18 & 19 \\
\hline Other $\mathrm{N}$ compounds & 7.48 & 53 \\
\hline Minor N compounds & 6.41 & 20 \\
\hline MUN & 1.53 & 21 \\
\hline Fat, $\%$ & 3.98 & 20 \\
\hline \multicolumn{3}{|l|}{ Traditional $\mathrm{MCP}^{3}$} \\
\hline $\mathrm{RCT}, \min$ & 19.6 & 39 \\
\hline $\mathrm{k}_{20}, \min$ & 5.3 & 70 \\
\hline $\mathrm{a}_{30}, \mathrm{~mm}$ & 34.9 & 54 \\
\hline $\mathrm{a}_{45}, \mathrm{~mm}$ & 46.8 & 35 \\
\hline $\mathrm{a}_{60}, \mathrm{~mm}$ & 49.7 & 29 \\
\hline \multicolumn{3}{|l|}{ Curd firming ${ }^{4}$} \\
\hline $\mathrm{RCT}_{\mathrm{eq}}, \min$ & 19.7 & 38 \\
\hline $\mathrm{CF}_{\mathrm{P}}, \mathrm{mm}$ & 68.8 & 26 \\
\hline $\mathrm{k}_{\mathrm{CF}}, \% \times \min ^{-1}$ & 7.6 & 26 \\
\hline $\mathrm{k}_{\mathrm{SR}}, \% \times \min ^{-1}$ & 0.6 & 39 \\
\hline $\mathrm{C}_{\max }, \mathrm{mm}$ & 51.3 & 26 \\
\hline $\mathrm{t}_{\max }, \min$ & 53.2 & 13 \\
\hline
\end{tabular}

${ }^{1} \mathrm{SCS}=\log _{2}(\mathrm{SCC} / 100,000)+3$.

${ }^{2}$ Contents of all protein fractions were measured by reversed-phase HPLC on skim milk and expressed as proportion on total milk $\mathrm{N}$. Protein $=$ whey protein + casein; whey protein $=$ sum of total whey fractions; casein $=$ sum of total casein fractions.

${ }^{3} \mathrm{MCP}=$ milk coagulation properties. $\mathrm{RCT}=$ rennet coagulation time; $\mathrm{k}_{20}=$ curd firming rate as minutes to a curd firmness of $20 \mathrm{~mm}$ $\mathrm{a}_{30(45,60)}=$ curd firmness after $30(45,60)$ min from rennet addition.

${ }^{4} \mathrm{RCT}_{\text {eq }}=$ rennet coagulation time estimated using the equation proposed by Bittante et al. (2013); $\mathrm{CF}_{\mathrm{P}}=$ asymptotic potential curd firmness; $\mathrm{k}_{\mathrm{CF}}=$ curd firming instant rate constant; $\mathrm{k}_{\mathrm{SR}}=$ syneresis instant rate constant; $\mathrm{CF}_{\max }=$ maximum curd firmness achieved within 45 $\min ; \mathrm{t}_{\max }=$ time at achievement of $\mathrm{CF}_{\max }$. there was substantial variation in the population. The highest variabilities were found for $\mathrm{k}_{20}(\mathrm{CV}=70 \%)$ and $\mathrm{a}_{30}(\mathrm{CV}=54 \%)$. The mean values of the $\mathrm{CF}_{\mathrm{t}}$ modeling parameters were as follows: $19.7 \mathrm{~min}$ for the coagulation time of each milk sample calculated on the basis of all 240 data points $\left(\mathrm{RCT}_{\mathrm{eq}}\right), 68.8 \mathrm{~mm}$ for the asymptotic potential curd firmness theoretically achievable at infinite time in absence of curd syneresis $\left(\mathrm{CF}_{\mathrm{P}}\right), 7.6 \%$ $\times \min ^{-1}$ for the instant rate constant of curd firming $\left(\mathrm{k}_{\mathrm{CF}}\right)$, and $1.39 \% \times \mathrm{min}^{-1}$ for the instant rate constant of syneresis $\left(\mathrm{k}_{\mathrm{SR}}\right)$. On average, the maximum $\mathrm{CF}$ value was $51.3 \mathrm{~mm}$ and was achieved $53.2 \mathrm{~min}$ after rennet addition. The values of all these $\mathrm{CF}_{\mathrm{t}}$ parameters are similar to those obtained by Stocco et al. (2017) using the entire database and a multibreed framework; further details and comments have already been reported in that study.

\section{Genetic and Herd-Date Variation in the SPP and in BHB}

Variance components as well as the estimates of intraherd heritabilities and the effects of herd-date (calculated as the proportion of total phenotypic variance) for blood metabolites are reported in Table 2 . The mean of the marginal posterior distribution of estimates suggests a small additive genetic influence on serum albumin concentrations, whereas total proteins, globulins, and the A:G exhibited moderate heritability $(\sim 0.20)$, in line with other studies that have revealed the existence of genetic variation for blood constituents (e.g., albumin, globulin fractions, total protein; Rowlands et al., 1974; Jensen and Christensen, 1975; Peterson et al., 1982). Blood BHB was instead found to have relatively high heritability (0.37), although it was in the range of published values (Oikonomou et al., 2008; van der Drift et al., 2012b; Belay et al., 2017b). This result indicates that it may be possible to select cows with lower blood BHB, although, considering the nature of the trait, it is clear that more accurate estimates might be obtained by focusing on early lactation. On the other hand, moderate to high herd-date effects were generally observed for blood metabolites, suggesting that management and feeding conditions may also play an important role in determining the health status of animals and in developing prevention strategies (Hardeng and Edge, 2001; Berge and Vertenten, 2014). For instance, previous data provided support for the influence of animal diet on blood serum protein concentration. Greater albumin serum concentrations were found in cows from higher producing herds, which are generally characterized by modern dairy systems in which animals were fed a silage-based TMR, compared 
with low producing herds, which are primarily based on traditional dairy management (Bobbo et al., 2016). Moreover, increasing dietary $\mathrm{CP}$ concentration from 144 to $173 \mathrm{~g} / \mathrm{kg}$ of DM caused an increase in plasma albumin and total protein concentrations in Holstein cows (Law et al., 2009).
It is worth mentioning, however, that routine collection of blood parameters at the population level is not plausible. A more rapid and less invasive alternative might be to use Fourier transform infrared spectroscopy analyses (Bittante and Cecchinato, 2013) to predict SPP levels in blood from milk. Studies are available for

Table 2. Estimates of genetic variance $\left(\sigma_{a}^{2}\right)$, herd-date variance $\left(\sigma_{h}^{2}\right)$, residual variance $\left(\sigma_{e}^{2}\right)$, heritability $\left(\mathrm{h}^{2}\right)$, and herd-date variance as proportion of total variance $\left(h_{\text {herd }}\right)$ for the investigated traits

\begin{tabular}{|c|c|c|c|c|c|c|c|}
\hline \multirow[b]{2}{*}{ Item } & \multicolumn{3}{|c|}{ Variance } & \multicolumn{2}{|c|}{$h^{21}$} & \multicolumn{2}{|c|}{$\mathrm{h}_{\text {herd }}{ }^{2}$} \\
\hline & $\sigma_{a}^{2}$ & $\sigma_{h}^{2}$ & $\sigma_{e}^{2}$ & Mean $^{3}$ & $\mathrm{PSD}^{4}$ & Mean $^{3}$ & $\mathrm{PSD}^{4}$ \\
\hline \multicolumn{8}{|l|}{ Serum protein pattern } \\
\hline Total protein, $\mathrm{g} / \mathrm{L}$ & 4.88 & 4.85 & 19.31 & 0.20 & 0.10 & 0.17 & 0.06 \\
\hline Albumin, g/L & 0.45 & 1.53 & 3.17 & 0.13 & 0.09 & 0.30 & 0.07 \\
\hline Globulin, g/L & 5.39 & 6.50 & 21.32 & 0.20 & 0.11 & 0.20 & 0.07 \\
\hline Albumin:globulin & $<0.01$ & $<0.01$ & $<0.01$ & 0.21 & 0.12 & 0.29 & 0.07 \\
\hline \multicolumn{8}{|l|}{ Udder health traits } \\
\hline SCS & 0.49 & 0.42 & 2.68 & 0.15 & 0.10 & 0.12 & 0.05 \\
\hline Lactose, \% & 0.10 & 0.66 & 0.39 & 0.20 & 0.13 & 0.57 & 0.08 \\
\hline $\mathrm{pH}$ & $<0.01$ & $<0.01$ & $<0.01$ & 0.19 & 0.10 & 0.51 & 0.08 \\
\hline Milk yield, kg/d & 6.40 & 34.36 & 29.07 & 0.18 & 0.11 & 0.49 & 0.07 \\
\hline True protein N, \% of total milk $\mathrm{N}$ & 3.28 & 4.71 & 9.01 & 0.27 & 0.11 & 0.28 & 0.08 \\
\hline \multicolumn{8}{|l|}{ Milk $\mathrm{N}$ fractions, ${ }^{5} \%$ of total milk $\mathrm{N}$} \\
\hline Caseins & 2.21 & 1.56 & 3.32 & 0.39 & 0.13 & 0.22 & 0.08 \\
\hline$\beta-\mathrm{LG}$ & 2.45 & 0.74 & 5.19 & 0.31 & 0.13 & 0.09 & 0.01 \\
\hline$\alpha-\mathrm{LA}$ & 0.04 & 0.02 & 0.12 & 0.24 & 0.11 & 0.11 & 0.02 \\
\hline Other $\mathrm{N}$ compounds & 3.25 & 4.68 & 9.04 & 0.26 & 0.13 & 0.26 & 0.08 \\
\hline Minor N compounds & 2.61 & 5.42 & 8.92 & 0.23 & 0.12 & 0.32 & 0.08 \\
\hline MUN & 0.04 & 0.48 & 0.22 & 0.14 & 0.07 & 0.65 & 0.04 \\
\hline Fat, \% & 0.42 & 0.26 & 0.48 & 0.46 & 0.16 & 0.22 & 0.07 \\
\hline \multicolumn{8}{|l|}{ Traditional $\mathrm{MCP}^{6}$} \\
\hline $\mathrm{RCT}, \min$ & 19.47 & 7.28 & 32.73 & 0.37 & 0.15 & 0.12 & 0.06 \\
\hline $\mathrm{k}_{20}, \min$ & 4.39 & 1.19 & 8.75 & 0.33 & 0.16 & 0.08 & 0.04 \\
\hline $\mathrm{a}_{30}, \mathrm{~mm}$ & 50.54 & 25.85 & 177.59 & 0.22 & 0.12 & 0.11 & 0.05 \\
\hline $\mathrm{a}_{45}, \mathrm{~mm}$ & 77.09 & 23.39 & 114.19 & 0.40 & 0.13 & 0.11 & 0.05 \\
\hline $\mathrm{a}_{60}, \mathrm{~mm}$ & 42.55 & 22.45 & 110.52 & 0.28 & 0.13 & 0.13 & 0.04 \\
\hline \multicolumn{8}{|l|}{ Curd firming $^{7}$} \\
\hline
\end{tabular}

${ }^{1} \mathrm{~h}^{2}=\sigma_{a}^{2} / \sigma_{a}^{2}+\sigma_{e}^{2}$.

${ }^{2} \mathrm{~h}_{\mathrm{herd}}=\sigma_{h}^{2} / \sigma_{a}^{2}+\sigma_{h}^{2}+\sigma_{e}^{2}$.

${ }^{3}$ Mean of the marginal posterior density of the parameter.

${ }^{4}$ Posterior standard deviation.

${ }^{5}$ Contents of all protein fractions were measured by reversed-phase HPLC on skim milk and expressed as proportion on total milk N. Total protein $=$ whey protein + casein; whey protein $=$ sum of total whey fractions; casein $=$ sum of total casein fractions

${ }^{6} \mathrm{MCP}=$ milk coagulation properties. $\mathrm{RCT}=$ rennet coagulation time; $\mathrm{k}_{20}=$ curd firming rate as minutes to a curd firmness of $20 \mathrm{~mm} ; \mathrm{a}_{30}(45,60$ $=$ curd firmness after $30(45,60)$ min from rennet addition.

${ }^{7} \mathrm{RCT}_{\mathrm{eq}}=$ rennet coagulation time estimated using the equation proposed by Bittante et al. (2013); $\mathrm{CF}_{\mathrm{P}}=$ asymptotic potential curd firmness; $\mathrm{k}_{\mathrm{CF}}=$ curd firming instant rate constant; $\mathrm{k}_{\mathrm{SR}}=$ syneresis instant rate constant; $\mathrm{CF}_{\max }=$ maximum curd firmness achieved within 45 min; $\mathrm{t}_{\max }$ $=$ time at achievement of $\mathrm{CF}_{\max }$. 
BHB, but no information on the predictive ability of Fourier transform infrared for SPP is yet available.

\section{Genetic and Herd-Date Variation in Udder Health Traits, Milk Production Traits, and Milk Coagulation Properties}

Estimates of variance components and heritability and effects of herd-date for udder health traits, milk production traits, and milk cheese-making properties are reported in Table 2. Regarding udder health traits, the heritability of SCS was 0.15 , in agreement with previous studies (Carlén et al., 2004; Cecchinato et al., 2011). Moderate heritabilities were observed for milk lactose and $\mathrm{pH}\left(\mathrm{h}^{2}=0.19\right.$ and 0.20 , respectively), whereas herd-date played the most important role $\left(\mathrm{h}_{\text {herd }}=0.57\right.$ and 0.51 , respectively). A recent multivariate factor analysis carried out on milk fatty acids and milk compositional traits associated SCC (positively) and lactose (negatively) to the same factor that was therefore named udder health (Mele et al., 2016). Moreover, milk $\mathrm{pH}$ has also been cited as a putative indicator of udder health (Bobbo et al., $2017 \mathrm{c}$ ). The SCS is a useful predictor of subclinical mastitis, and is therefore related to milk quality and technological characteristics (Ogola et al., 2007). A high milk SCC is associated with lower milk lactose, generally as a result of tissue damage during mastitis and a reduction in the synthetic ability of the enzyme systems of the secretory cells, and could therefore be used as an indicator of mastitis (Pyörälä, 2003). The average value of SCS (3.04) can be considered as an indicator of high overall milk quality, suggesting the presence of few cases of IMI and subclinical mastitis. On the other hand, milk $\mathrm{pH}$ increases with increasing SCC (Vianna et al., 2008); indeed, mastitis can also be detected via changes in milk $\mathrm{pH}$ even if this method may impair sensitivity (Viguier et al., 2009). Moreover, SCS and milk pH have exhibited positive (unfavorable) genetic correlations with RCT (Cecchinato et al., 2011; Bittante et al., 2012) and have therefore been advocated as interesting candidates for indirect genetic improvement of milk properties for cheese-making.

The concentrations and composition of protein in milk are largely unresponsive to variations in nutritional and management conditions. Variations in milk protein have been found to be mostly under genetic control (Schopen et al., 2011; Pegolo et al., 2018), but the herd-date also made a moderate contribution to explaining the variability observed in $\alpha_{\mathrm{S}_{1}} \mathrm{CN}\left(\mathrm{h}_{\text {herd }}=\right.$ 0.27 ; Table 2), in contrast with previous results showing small herd effects on all milk protein fractions (Schopen et al., 2009). The heritability of MUN was relatively low (0.14), whereas herd-date effect explained $65 \%$ of MUN variation, confirming that modifications in herd management can considerably reduce MUN and improve the efficiency of $\mathrm{N}$ utilization (Godden et al., 2001; Stoop et al., 2007). The heritability values for milk fat were high (0.46) but in line with previous data for Holsteins and confirm the role of major genes (e.g., diacylglycerol O-acyltransferase 1) that underlie the large genetic variation in milk fat percentages found in this breed (Grisart et al., 2002; Schennink et al., 2007).

We also evaluated the genetic parameters for traditional single-point milk coagulation properties and, for the first time, curd firmness modeling parameters $\left(\mathrm{CF}_{\mathrm{t}}\right)$ in Holstein Friesian cows. Milk coagulation properties and $\mathrm{CF}_{\mathrm{t}}$ modeling parameters were characterized by moderate to high heritabilities $(>0.22)$, whereas lower values have been reported for other breeds (i.e., Brown Swiss; Cecchinato et al., 2015). On the other hand, factors associated with herd management did not significantly affect milk technological characteristics, confirming that improvement in cheese-making ability of milk is fundamentally affected by genetics and largely by the content of the major milk proteins and their genetic polymorphisms (Bittante et al., 2012; Poulsen et al., 2013).

\section{Genetic and Environmental Relationships Between SPP and BHB}

We report here the first estimates of genetic and environmental relationships among SPP and BHB in dairy cows (Tables 3; Supplemental Table S1, https:// doi.org/10.3168/jds.2018-14907). Negative genetic correlations were found between BHB and total proteins $(-0.428)$ and between BHB and globulins $(-0.619)$, whereas strong positive genetic correlations were found between BHB and serum albumin (0.629) and between BHB and A:G (0.717; Table 3). Blood metabolites, including globulins and albumin, change over the lactation period according to metabolic adaptation and they can be indicators of hepatic damage and impaired function (Ronge et al., 1988; Aeberhard et al., 2001; González et al., 2011). For instance, the high lipomobilization occurring during NEB in dairy cows can compromise liver function and trigger metabolic alterations, such as fatty liver and ketosis (González et al., 2011). Our results showed that beyond pathological conditions (e.g., ketosis), variations in SPP and BHB blood levels in clinically healthy cows are likely to be genetically related. On the other hand, the environmental relationships between BHB and blood serum proteins were not relevant (Supplemental Table S1). 
Table 3. Estimates (SD) of additive genetic relationships among total protein, albumin, globulin, albumin: globulin ratio, and $\mathrm{BHB}^{1}$

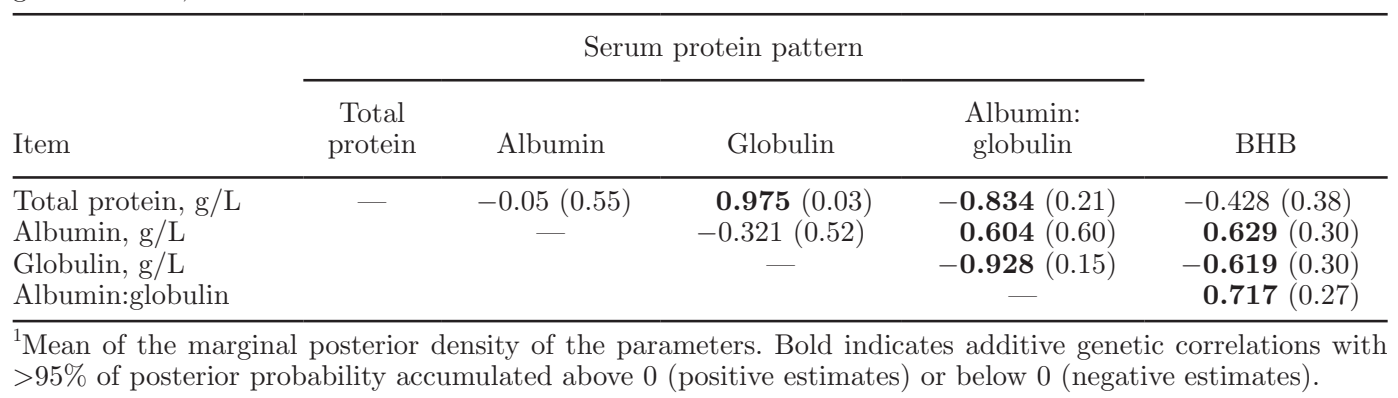

\section{Genetic and Environmental Relationships Between SPP and Udder Health Traits, Milk Production Traits, and Milk Coagulation Properties}

The genetic and environmental relationships between blood serum proteins and udder health traits, milk production traits, and milk coagulation properties are presented in Table 4 and Supplemental Tables S2 and S3 (https://doi.org/10.3168/jds.2018-14907). Serum albumin exhibits a very weak positive genetic correlation with $\alpha$-LA, whereas serum globulin and $\beta$-LG were even negatively correlated $(-0.571)$. Serum proteins were found to have strong negative genetic correlations with lactose $(-0.763)$, true milk protein $\mathrm{N}$ $(-0.649), \beta-\mathrm{LG}(-0.667)$, and fat $(-0.854)$ but positive genetic correlations with milk $\mathrm{pH}$ (0.669), other $\mathrm{N}$ compounds (0.604), and minor $\mathrm{N}$ compounds (0.605; Table 4). Looking at individual blood serum proteins, the strongest negative associations were found between serum albumin and the milk fat percentage $(-0.894)$ and between serum globulin and $\alpha_{\mathrm{S}_{2}} \mathrm{CN}(-0.610$; Table 4). The fatty acids in the milk of ruminants derive from 2 sources: uptake from the bloodstream and de novo synthesis within the mammary epithelial cells (Barber et al., 1997). Nonesterified fatty acids, which originate from digestion and absorption of dietary lipids and from mobilization of body fat reserves, are typically transported in the blood by albumin (Contreras and Sordillo, 2011). It is possible that an increase in blood serum albumin levels increases the uptake of fatty acids into the mammary gland, which in turn reduces endogenous synthesis. On the other hand, serum globulin synthesis or metabolism seemed to be genetically related mainly to the milk protein $\left(\alpha_{\mathrm{S}^{-}} \mathrm{CN}\right)$ proportion. Changes in milk protein content and composition can affect the nutritional and manufacturing properties of milk. The biological function of caseins is to transport calcium and phosphate to the offspring and to form a clot in the stomach to improve the efficiency of nutrient supply (Boirie et al., 1997; Hoffman and Falvo, 2004).
The milk casein content also plays a fundamental role in milk coagulation during the cheese-making process (Bittante et al., 2012). Although the observed genetic correlations between blood serum proteins and milk coagulation properties were not relevant, cows with low levels of blood serum globulin tended to have short $\mathrm{k}_{20}$ and high curd firmness values (e.g., $\mathrm{a}_{60}, \mathrm{CF}_{\mathrm{p}}, \mathrm{C}_{\max }$; Table 4).

Strong herd-date relationships were found between total serum proteins and milk protein composition, which were positive for $\kappa-\mathrm{CN}(0.673), \alpha_{\mathrm{S} 1}-\mathrm{CN}$ (0.561), and $\beta-\mathrm{LG}(0.573)$ and negative for $\alpha_{\mathrm{S}_{2}} \mathrm{CN}(-0.582)$ and $\alpha$-LA ( -0.635 ; Supplemental Table S2). These results might be related to differential effects of IMI on the degree of proteolysis of the various protein fractions. Nonetheless, we did not find any relevant correlations between blood serum proteins and milk coagulation properties due to the herd-date effect (Supplemental Table S2).

\section{Genetic and Environmental Relationships Between BHB and Udder Health Traits, Milk Production Traits, and Milk Coagulation Properties}

Estimates of the additive genetic correlations for BHB and udder health traits, milk production traits, and milk coagulation properties are presented in Table 4. A positive genetic correlation was found between BHB and milk yield (0.716), even if higher than previous findings (Belay et al., 2017b). This was expected because selection for high milk production has resulted in an increased risk of NEB and greater body fat mobilization (Veerkamp et al., 2003; Coffey et al., 2004). However, because this correlation was not equal to 1 , it suggests that there is potential to select for greater milk yield without increasing BHB. On the other hand, cows with low levels of BHB should better manage the increase in energy requirements during lactation and have a lower risk of NEB or a fast recovery rate (robustness) because they exhibit lesser weight loss or 
more efficient utilization of ketone bodies from lipomobilization of fat reserves.

Only weak genetic correlations were found between BHB and both udder health and other milk production traits. Blood BHB was positively associated with milk lactose, true protein $\mathrm{N}$, and fat proportions and negatively associated with SCS, milk pH, and NPN (Table 4). These results contrast somewhat with previous findings (Belay et al., 2017b), which showed lower BHB to be genetically associated with higher milk protein and lactose percentages (although to a small extent). However, it is worth mentioning that these authors measured blood BHB levels only in early lactation and found that the strength of association decreased with advancing lactation for these 2 traits. On the other hand, blood BHB had a strong genetic relationship with MUN ( -0.659 ; Table 4$)$. Urea is produced by protein breakdown, and the peripheral urea $\mathrm{N}$ concentration is strictly related to protein metabolism in dairy cattle. Energy shortage may induce catabolism of AA from tissue proteins and increase urea production (Bell, 1995). In addition, impairment in liver function occurring during NEB can reduce the metabolic clearance of urea (O'Callahan et al., 2001).

We also report the first estimates of genetic correlations between blood BHB and milk protein composition and coagulation properties (Table 4). There seemed to be only weak associations between blood BHB and milk protein fractions, which were negative in the case of $\beta-\mathrm{CN}$ and $\alpha_{\mathrm{S1}^{-}} \mathrm{CN}$ and positive for $\kappa-\mathrm{CN}$ and whey

Table 4. Estimates of additive genetic (SD) relationships between serum proteins (total protein, albumin, globulin, albumin:globulin ratio, and $\mathrm{BHB}$ ) and udder health traits, milk production, milk $\mathrm{N}$ fractions, fat percentage, milk coagulation properties (MCP), and curd firming modeling ${ }^{1}$

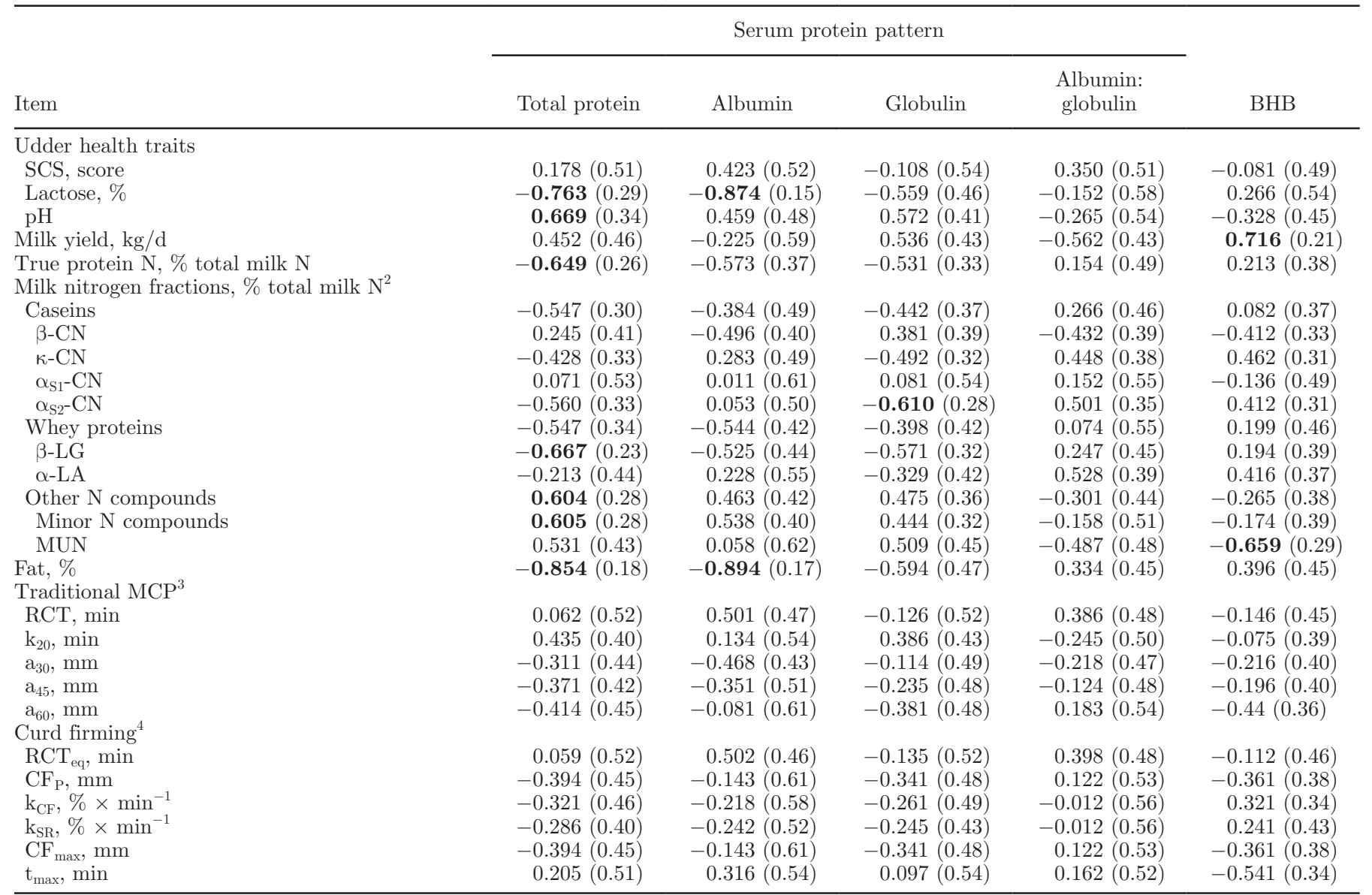

${ }^{1}$ Mean of the marginal posterior density of the parameters. Bold indicates additive genetic correlations with $>95 \%$ of posterior probability accumulated above 0 (positive estimates) or below 0 (negative estimates).

${ }^{2}$ Contents of all protein fractions were measured by reversed-phase HPLC on skim milk and expressed as proportion on total milk N. Total protein $=$ whey protein + casein; whey protein $=$ sum of total whey fractions; casein $=$ sum of total casein fractions.

${ }^{3} \mathrm{RCT}=$ rennet coagulation time; $\mathrm{k}_{20}=$ curd firming rate as minutes to a curd firmness of $20 \mathrm{~mm} ; \mathrm{a}_{30}(45,60)=$ curd firmness after $30(45,60)$ min from rennet addition.

${ }^{4} \mathrm{RCT}_{\mathrm{eq}}=$ rennet coagulation time estimated using the equation proposed by Bittante et al. (2013); $\mathrm{CF}_{\mathrm{P}}=$ asymptotic potential curd firmness; $\mathrm{k}_{\mathrm{CF}}=$ curd firming instant rate constant; $\mathrm{k}_{\mathrm{SR}}=$ syneresis instant rate constant; $\mathrm{CF}_{\max }=$ maximum curd firmness achieved within 45 min; $\mathrm{t}_{\max }$ $=$ time at achievement of $\mathrm{CF}_{\max }$. 
proteins. Accordingly, no relevant genetic associations between blood BHB and the cheese-making properties of milk were found (Table 4).

We also determined herd-date correlations between blood BHB and udder health and milk production traits (Supplemental Table S2, https://doi.org/10 .3168/jds.2018-14907). Very strong negative herd-date correlations were found between blood BHB and $\kappa-\mathrm{CN}$ $(-0.836)$, which suggests that the management and environmental conditions resulting in lower levels of blood BHB are associated with the production of milk with a higher $\kappa-\mathrm{CN}$ proportion. Management and feeding conditions are major determinants of peripartum diseases in dairy cows. For instance, avoiding excessive lipid mobilization is fundamental for preventing the occurrence of metabolic disorders. Holtenius et al. (2003) showed that nonesterified fatty acid concentration in plasma during the postparturient period was higher in cows fed a higher energy level during the dry period, which suggested that lipomobilization was inversely related to DMI during the prepartum period. Moreover, stressors related to management (e.g., grouping and space allowance) and environmental (e.g., heat and humidity) conditions have well-known negative effects on DMI, the immune system, health, reproduction, and production (Konggaard and Krohn, 1978; Davis, 1998; West, 2003). Nutrition appears to have little effect on the synthesis of the major milk proteins by mammary secretory cells (MacRae et al., 2000). On the other hand, heat stress was shown to increase systemic AA utilization, which limits the AA supply to the mammary gland for the synthesis of milk proteins (Gao et al., 2017).

Given that $\kappa-\mathrm{CN}$ plays a pivotal role in determining milk technological characteristics (Bittante et al., 2012; Pegolo et al., 2018), strong environmental correlations were also found between blood BHB and milk coagulation properties, positive for $\mathrm{k}_{20}$ and negative for curd firmness traits (e.g., $\mathrm{a}_{30}$ and $\mathrm{CF}_{\mathrm{P}}$; Supplemental Table S2). Therefore, improving animal health and welfare through a herd-level approach might also have positive effects on milk cheese-making.

\section{CONCLUSIONS}

The results of this study show that additive genetic variation exists for blood indicators of animal welfare and udder health traits, which could be exploited for genetic improvement of cows' robustness. It is clear, however, that more studies are needed to validate and confirm our findings, likely involving a larger population or other breeds. The genetic relationships between SPP and udder health indicator traits (which were negative for milk lactose and positive for milk $\mathrm{pH}$ ) support the hypothesis that blood serum proteins might be considered as indicators of mammary gland inflammation. Moreover, the strong genetic correlations between SPP and BHB suggest that variation in SPP might also be related to metabolic disorders such as hyperketonemia. However, more accurate information could be derived from the estimation of correlation with the infection or disease event (e.g., mastitis or ketosis). On the other hand, our results did not support a role of SPP and BHB as indicators of milk quality and cheese-making aptitude because only few and no relevant genetic correlations were found with milk quality traits and technological characteristics, respectively. Before a possible incorporation of SPP within dairy cattle breeding programs, more information is needed about the physiological and molecular mechanisms underlying the relationships between these indicators of animal health and phenotypes related to milk quality and cheese-making aptitude (e.g., through integration with genomic data).

\section{ACKNOWLEDGMENTS}

The authors thank the Autonomous Province of Trento (Italy) for funding. The authors also acknowledge Enrico Fiore, Matteo Gianesella, and Massimo Morgante (Dipartimento di Medicina Animale, Produzioni e Salute, University of Padua, Legnaro, Italy) for blood sample collection and analyses and Claudio CipolatGotet and Giorgia Stocco (Department of Agronomy, Food, Natural Resources, Animals and Environment, University of Padua, Legnaro, Italy) for milk quality assessment.

\section{REFERENCES}

Aeberhard, K., R. M. Bruckmaier, and J. W. Blum. 2001. Metabolic, enzymatic and endocrine status in high-yielding dairy cows-Part 2. J. Vet. Med. A Physiol. Pathol. Clin. Med. 48:111-127.

Alberghina, D., S. Casella, I. Vazzana, V. Ferrantelli, C. Giannetto, and G. Piccione. 2010. Analysis of serum proteins in clinically healthy goats (Capra hircus) using agarose gel electrophoresis. Vet. Clin. Pathol. 39:317-321.

Ali, A. K. A., and G. E. Shook. 1980. An optimum transformation for somatic cell concentration in milk. J. Dairy Sci. 63:487-490.

Barber, M. C., R. A. Clegg, M. T. Travers, and R. G. Vernon. 1997. Lipid metabolism in the lactating mammary gland. Biochim. Biophys. Acta Lipids Lipid Metab. 1347:101-126.

Belay, T. K., B. S. Dagnachew, Z. M. Kowalski, and T. Ådnøy. 2017a. An attempt at predicting blood $\beta$-hydroxybutyrate from Fouriertransform mid-infrared spectra of milk using multivariate mixed models in Polish dairy cattle. J. Dairy Sci. 100:6312-6326.

Belay, T. K., M. Svendsen, Z. M. Kowalski, and T. Ådnøy. 2017b. Genetic parameters of blood $\beta$-hydroxybutyrate predicted from milk infrared spectra and clinical ketosis, and their associations with milk production traits in Norwegian Red cows. J. Dairy Sci. 100:6298-6311.

Bell, A. W. 1995. Regulation of organic nutrient metabolism during transition from late pregnancy to early lactation. J. Anim. Sci. 73:2804-2819. 
Berge, A. C., and G. Vertenten. 2014. A field study to determine the prevalence, dairy herd management systems, and fresh cow clinical conditions associated with ketosis in western European dairy herds. J. Dairy Sci. 97:2145-2154.

Bernabucci, U., L. Basiricò, P. Morera, D. Dipasquale, A. Vitali, F. Piccioli Cappelli, and L. Calamari. 2015. Effect of summer season on milk protein fractions in Holstein cows. J. Dairy Sci. 98:18151827.

Bittante, G., and A. Cecchinato. 2013. Genetic analysis of the Fourier transform infrared spectra of bovine milk with emphasis on individual wavelengths related to specific chemical bonds. J. Dairy Sci. 96:5991-6006.

Bittante, G., B. Contiero, and A. Cecchinato. 2013. Prolonged observation and modelling of milk coagulation, curd firming, and syneresis. Int. Dairy J. 29:115-123.

Bittante, G., M. Penasa, and A. Cecchinato. 2012. Invited review: Genetics and modeling of milk coagulation properties. J. Dairy Sci. 95:6843-6870.

Blasco, A. 2005. The use of Bayesian statistics in meat quality analyses: A review. Meat Sci. 69:115-122.

Bobbo, T., C. Cipolat-Gotet, G. Bittante, and A. Cecchinato. 2016. The nonlinear effect of somatic cell count on milk composition, coagulation properties, curd firmness modeling, cheese yield, and curd nutrient recovery. J. Dairy Sci. 99:5104-5119.

Bobbo, T., E. Fiore, M. Gianesella, M. Morgante, L. Gallo, P. L. Ruegg, G. Bittante, and A. Cecchinato. 2017a. Variation in blood serum proteins and association with somatic cell count in dairy cattle from multi-breed herds. Animal 11:2309-2319.

Bobbo, T., P. L. Ruegg, E. Fiore, M. Gianesella, M. Morgante, D. Pasotto, L. Gallo, G. Bittante, and A. Cecchinato. 2017b. Short communication: Association between udder health status and blood serum proteins in dairy cows. J. Dairy Sci. 100:9775-9780.

Bobbo, T., P. L. Ruegg, G. Stocco, E. Fiore, M. Gianesella, M. Morgante, D. Pasotto, G. Bittante, and A. Cecchinato. 2017c. Associations between pathogen-specific cases of subclinical mastitis and milk yield, quality, protein composition, and cheese-making traits in dairy cows. J. Dairy Sci. 100:4868-4883.

Bobe, G., D. C. Beitz, A. E. Freeman, and G. L. Lindberg. 1998. Separation and quantification of bovine milk proteins by reversed-phase high-performance liquid chromatography. J. Agric. Food Chem. 46:458-463.

Boirie, Y., M. Dangin, P. Gachon, M. P. Vasson, J. L. Maubois, and B. Beaufrère. 1997. Slow and fast dietary proteins differently modulate postprandial protein accretion. Proc. Natl. Acad. Sci. USA 94:14930-14935.

Buitenhuis, B., N. A. Poulsen, G. Gebreyesus, and L. B. Larsen. 2016. Estimation of genetic parameters and detection of chromosomal regions affecting the major milk proteins and their post translational modifications in Danish Holstein and Danish Jersey cattle. BMC Genet. 17:114.

Busher, J. T. 1990. Serum albumin and globulin. Pages 497-499 in Clinical Methods: The History, Physical, and Laboratory Examinations. 3rd ed. H. K. Walker, W. D. Hall, and J. W. Hurst, ed. Butterworths, Boston, MA.

Carlén, E., E. Strandberg, and A. Roth. 2004. Genetic parameters for clinical mastitis, somatic cell score, and production in the first three lactations of Swedish Holstein cows. J. Dairy Sci. 87:30623070 .

Cecchinato, A., S. Chessa, C. Ribeca, C. Cipolat-Gotet, T. Bobbo, J. Casellas, and G. Bittante. 2015. Genetic variation and effects of candidate-gene polymorphisms on coagulation properties, curd firmness modeling and acidity in milk from Brown Swiss cows. Animal 9:1104-1112.

Cecchinato, A., M. Penasa, M. De Marchi, L. Gallo, G. Bittante, and P. Carnier. 2011. Genetic parameters of coagulation properties, milk yield, quality, and acidity estimated using coagulating and noncoagulating milk information in Brown Swiss and HolsteinFriesian cows. J. Dairy Sci. 94:4205-4213.

Coffey, M. P., G. Simm, J. D. Oldham, W. G. Hill, and S. Brotherstone. 2004. Genotype and diet effects on energy balance in the first three lactations of dairy cows. J. Dairy Sci. 87:4318-4326.
Contreras, G. A., and L. M. Sordillo. 2011. Lipid mobilization and inflammatory responses during the transition period of dairy cows. Comp. Immunol. Microbiol. Infect. Dis. 34:281-289.

Cozzi, G., L. Ravarotto, F. Gottardo, A. L. Stefani, B. Contiero, L. Moro, M. Brscic, and P. Dalvit. 2011. Short communication: Reference values for blood parameters in Holstein dairy cows: Effects of parity, stage of lactation, and season of production. J. Dairy Sci. 94:3895-3901.

Davis, S. L. 1998. Environmental modulation of the immune system via the endocrine system. Domest. Anim. Endocrinol. 15:283-289.

Denis-Robichaud, J., J. Dubuc, D. Lefebvre, and L. DesCôteaux. 2014. Accuracy of milk ketone bodies from flow-injection analysis for the diagnosis of hyperketonemia in dairy cows. J. Dairy Sci. 97:3364-3370

Doumas, B. T., W. A. Watson, and H. G. Biggs. 1971. Albumin standards and the measurement of serum albumin with bromcresol green. Clin. Chim. Acta 31:87-96.

Gain, S., J. Mukherjee, S. Chatterjee, S. Batabyal, and C. Guha. 2015 Alteration in the activity of blood and milk leukocytes together with the serum enzyme profile during sub-clinical mastitis in crossbred cows. Indian J. Anim. Sci. 85:856-860.

Gao, S. T., J. Guo, S. Y. Quan, X. M. Nan, M. V. S. Fernandez, L. H. Baumgard, and D. P. Bu. 2017. The effects of heat stress on protein metabolism in lactating Holstein cows. J. Dairy Sci. 100:5040-5049.

Giuliotti, L., M. N. Benvenuti, I. Facdouelle, and J. Goracci. 2004. Blood Parameters: Potential Welfare Indicators in Dairy Cows. Annali della Facolta di Medicina Veterinaria di Pisa 57, 281-289.

Godden, S. M., K. D. Lissemore, D. F. Kelton, K. E. Leslie, J. S. Walton, and J. H. Lumsden. 2001. Relationships between milk urea concentrations and nutritional management, production, and economic variables in Ontario dairy herds. J. Dairy Sci. 84:1128-1139.

González, F. D., R. Muiño, V. Pereira, R. Campos, and J. L. Benedito. 2011. Relationship among blood indicators of lipomobilization and hepatic function during early lactation in high-yielding dairy cows. J. Vet. Sci. 12:251-255.

Gornall, A. G., C. J. Bardawill, and M. M. David. 1949. Determination of serum proteins by means of the biuret reaction. J. Biol. Chem. 177:751-766.

Grelet, C., C. Bastin, M. Gelé, J.-B. Davière, M. Johan, A. Werner, R. Reding, J. A. Fernandez Pierna, F. G. Colinet, P. Dardenne, N. Gengler, H. Soyeurt, and F. Dehareng. 2016. Development of Fourier transform mid-infrared calibrations to predict acetone, $\beta$-hydroxybutyrate, and citrate contents in bovine milk through a European dairy network. J. Dairy Sci. 99:4816-4825.

Grisart, B., W. Coppieters, F. Farnir, L. Karim, C. Ford, P. Berzi, N. Cambisano, M. Mni, S. Reid, P. Simon, R. Spelman, M. Georges, and R. Snell. 2002. Positional candidate cloning of a QTL in dairy cattle: Identification of a missense mutation in the bovine DGAT1 gene with major effect on milk yield and composition. Genome Res. 12:222-231.

Hardeng, F., and V. L. Edge. 2001. Mastitis, ketosis, and milk fever in 31 organic and 93 conventional Norwegian dairy herds. J. Dairy Sci. 84:2673-2679.

Hoffman, J. R., and M. J. Falvo. 2004. Protein-Which is best? J. Sports Sci. Med. 3:118-130.

Holtenius, K., S. Agenas, C. Delavaud, and Y. Chilliard. 2003. Effects of feeding intensity during the dry period. 2. Metabolic and hormonal responses. J. Dairy Sci. 86:883-891.

Jensen, P. T., and K. Christensen. 1975. Genetic analysis of the serum level of IgG and total protein in Red Danish cattle. J. Anim. Sci. 40:392-396.

Jõudu, I., M. Henno, T. Kaart, T. Püssa, and O. Kärt. 2008. The effect of milk protein contents on the rennet coagulation properties of milk from individual dairy cows. Int. Dairy J. 18:964-967.

Kaneko, J. J., J. W. Harvey, and M. Bruss. 2008. Clinical Biochemistry of Domestic Animals. Elsevier/Academic Press, Burlington, MA.

Konggaard, S. P., and C. C. Krohn. 1978. Performance of First-Calf Heifers in Two Different Grouping Systems. Rep. Nat. Inst. Anim. Sci., Copenhagen, Denmark. 
Law, R. A., F. J. Young, D. C. Patterson, D. J. Kilpatrick, A. R. G. Wylie, and C. S. Mayne. 2009. Effect of dietary protein content on animal production and blood metabolites of dairy cows during lactation. J. Dairy Sci. 92:1001-1012.

MacRae, J. C., B. J. Bequette, and L. A. Crompton. 2000. Synthesis of milk protein and opportunities for nutritional manipulation. Pages 179-199 in British Society of Animal Science Occasional Publication No. 25. R. E. Agnew, K. W. Agnew, and A. M. Fearon, ed. British Society of Animal Science, Edinburgh, UK.

Maurmayr, A., A. Cecchinato, L. Grigoletto, and G. Bittante. 2013. Detection and quantification of $\alpha \mathrm{S} 1-, \alpha \mathrm{S} 2-, \beta-, \kappa$-casein, $\alpha$-lactalbumin, $\beta$-lactoglobulin and lactoferrin in bovine milk by reverse-phase high-performance liquid chromatography. Agric. Conspectus Scientificus 78:201-205.

Mele, M., N. P. P. Macciotta, A. Cecchinato, G. Conte, S. Schiavon, and G. Bittante. 2016. Multivariate factor analysis of detailed milk fatty acid profile: Effects of dairy system, feeding, herd, parity, and stage of lactation. J. Dairy Sci. 99:9820-9833.

Mulligan, F. J., L. O'Grady, D. A. Rice, and M. L. Doherty. 2006. A herd health approach to dairy cow nutrition and production diseases of the transition cow. Anim. Reprod. Sci. 96:331-353.

O'Callahan, D., J. M. Lozano, J. Fahey, V. Gath, S. Snijders, and M. P. Boland. 2001. Relationships between nutrition and fertility in cattle. Pages 147-160 in British Society of Animal Science Occasional Publication No. 26. Nottingham University Press, Edinburgh, UK.

O'Rourke, D. 2009. Nutrition and udder health in dairy cows: A review. Ir. Vet. J. 62(Suppl. 4):S15-S20.

Ogola, H., A. Shitandi, and J. Nanua. 2007. Effect of mastitis on raw milk compositional quality. J. Vet. Sci. 8:237-242.

Oikonomou, G., G. E. Valergakis, G. Arsenos, N. Roubies, and G. Banos. 2008. Genetic profile of body energy and blood metabolic traits across lactation in primiparous Holstein cows. J. Dairy Sci. 91:2814-2822.

Overton, T. R., J. A. A. Mcart, and D. V. Nydam. 2017. A 100year review: Metabolic health indicators and management of dairy cattle. J. Dairy Sci. 100:10398-10417.

Pegolo, S., N. Mach, Y. Ramayo-Caldas, S. Schiavon, G. Bittante, and A. Cecchinato. 2018. Integration of GWAS, pathway and network analyses reveals novel mechanistic insights into the synthesis of milk proteins in dairy cows. Sci. Rep. 8:566.

Peterson, R. G., T. E. Nash, and J. A. Shelford. 1982. Heritabilities and genetic correlations for serum and production traits of lactating Holsteins. J. Dairy Sci. 65:1556-1561.

Piccinini, R., E. Binda, M. Belotti, G. Casirani, and A. Zecconi. 2004. The evaluation of non-specific immune status of heifers in field conditions during the periparturient period. Vet. Res. 35:539-550.

Poulsen, N. A., H. P. Bertelsen, H. B. Jensen, F. Gustavsson, M. Glantz, H. Lindmark Månsson, A. Andrén, M. Paulsson, C. Bendixen, A. J. Buitenhuis, and L. B. Larsen. 2013. The occurrence of noncoagulating milk and the association of bovine milk coagulation properties with genetic variants of the caseins in 3 Scandinavian dairy breeds. J. Dairy Sci. 96:4830-4842.

Pyörälä, S. 2003. Indicators of inflammation in the diagnosis of mastitis. Vet. Res. 34:565-578. https://doi.org/10.1051/vetres:2003026.

Ronge, H., J. Blum, C. Clement, F. Jans, H. Leuenberger, and H. Binder. 1988. Somatomedin C in dairy cows related to energy and protein supply and to milk production. Anim. Prod. 47:165-183.

Rowlands, G. J., J. M. Payne, S. M. Dew, and R. Manston. 1974. Individuality and heritability of the blood composition of calves with particular reference to the selection of stock with improved growth potential. J. Agric. Sci. 82:473-481.

Schennink, A., W. M. Stoop, M. H. P. W. Visker, J. M. L. Heck, H. Bovenhuis, J. J. Van Der Poel, H. J. F. Van Valenberg, and J. A. M. Van Arendonk. 2007. DGAT1 underlies large genetic variation in milk-fat composition of dairy cows. Anim. Genet. 38:467-473.
Schopen, G. C. B., J. M. L. Heck, H. Bovenhuis, M. H. P. W. Visker, H. J. F. van Valenberg, and J. A. M. van Arendonk. 2009. Genetic parameters for major milk proteins in Dutch Holstein-Friesians. J. Dairy Sci. 92:1182-1191.

Schopen, G. C. B., M. H. P. W. Visker, P. D. Koks, E. Mullaart, J. A. M. van Arendonk, and H. Bovenhuis. 2011. Whole-genome association study for milk protein composition in dairy cattle. J. Dairy Sci. 94:3148-3158.

Stocco, G., C. Cipolat-Gotet, T. Bobbo, A. Cecchinato, and G. Bittante. 2017. Breed of cow and herd productivity affect milk composition and modeling of coagulation, curd firming, and syneresis. J. Dairy Sci. 100:129-145.

Stoop, W. M., H. Bovenhuis, and J. A. M. van Arendonk. 2007. Genetic parameters for milk urea nitrogen in relation to milk production traits. J. Dairy Sci. 90:1981-1986.

Sturaro, E., E. Marchiori, G. Cocca, M. Penasa, M. Ramanzin, and G. Bittante. 2013. Dairy systems in mountainous areas: Farm animal biodiversity, milk production and destination, and land use. Livest. Sci. 158:157-168.

Tuck, M. K., D. W. Chan, D. Chia, A. K. Godwin, W. E. Grizzle, K. E. Krueger, W. Rom, M. Sanda, L. Sorbara, S. Stass, W. Wang, and D. E. Brenner. 2009. Standard operating procedures for serum and plasma collection: Early detection research network consensus statement standard operating procedure integration working group. J. Proteome Res. 8:113-117.

van der Drift, S. G. A., R. Jorritsma, J. T. Schonewille, H. M. Knijn, and J. A. Stegeman. 2012a. Routine detection of hyperketonemia in dairy cows using Fourier transform infrared spectroscopy analysis of $\beta$-hydroxybutyrate and acetone in milk in combination with test-day information. J. Dairy Sci. 95:4886-4898.

van der Drift, S. G. A., K. J. E. van Hulzen, T. G. Teweldemedhn, R. Jorritsma, M. Nielen, and H. C. M. Heuven. 2012b. Genetic and nongenetic variation in plasma and milk $\beta$-hydroxybutyrate and milk acetone concentrations of early-lactation dairy cows. J. Dairy Sci. 95:6781-6787.

Veerkamp, R. F., B. Beerda, and T. Van Der Lende. 2003. Effects of genetic selection for milk yield on energy balance, levels of hormones, and metabolites in lactating cattle, and possible links to reduced fertility. Livest. Prod. Sci. 83:257-275.

Vianna, P. C. B., G. Mazal, M. V. Santos, H. M. A. Bolini, and M. L. Gigante. 2008. Microbial and sensory changes throughout the ripening of Prato cheese made from milk with different levels of somatic cells. J. Dairy Sci. 91:1743-1750.

Viguier, C., S. Arora, N. Gilmartin, K. Welbeck, and R. O'Kennedy. 2009. Mastitis detection: Current trends and future perspectives. Trends Biotechnol. 27:486-493.

Wankhade, P. R., A. Manimaran, A. Kumaresan, S. Jeyakumar, K. P. Ramesha, V. Sejian, D. Rajendran, and M. R. Varghese. 2017. Metabolic and immunological changes in transition dairy cows: A review. Vet. World 10:1367-1377.

Wedholm, A., L. B. Larsen, H. Lindmark-Månsson, A. H. Karlsson, and A. Andrén. 2006. Effect of protein composition on the cheesemaking properties of milk from individual dairy cows. J. Dairy Sci. 89:3296-3305.

West, J. W. 1999. Nutritional strategies for managing the heat-stressed dairy cow. J. Anim. Sci. 77(Suppl. 2):21-35.

West, J. W. 2003. Effects of heat-stress on production in dairy cattle. J. Dairy Sci. 86:2131-2144.

Wright, S. 1922. Coefficients of inbreeding and relationship. Am. Nat. $56: 330-338$.

Yang, Y. X., X. Zhao, and Y. Zhang. 2009. Proteomic analysis of mammary tissues from healthy cows and clinical mastitic cows for identification of disease-related proteins. Vet. Res. Commun. $33: 295-303$. 